\title{
A REVIEW ON STABILIZATION OF SOIL USING BIO-ENZYME
}

\author{
Vijay Rajoria $^{1}$, Suneet Kaur $^{2}$ \\ ${ }^{1}$ M.Tech Scholar, ${ }^{2}$ Associate Professor, Maulana Azad National Institute of Technology, Bhopal, India,
}

\begin{abstract}
In developing countries like India the most important requirement of any project after performance criteria is its economical feasibility and serviceability criteria. The conventional methods are time consuming and are not economically feasible. Hence there is a need to discover the other possible ways to satisfy the performance as well as economical criteria. In this paper, popularly available bio-enzymes and their effect on engineering properties of soil are discussed. The stabilization of soil with bio-enzyme is a revolutionary technique which becoming popular worldwide. Recently there are many bio-enzymes available for soil stabilization such as renolith, Perma-Zyme, Terra-Zyme, Fujibeton etc. These enzymes have been proven to be very effective and economical. Another advantage of the bio-enzyme is that these are environment friendly. When these bio-enzymes are mixed with soil they alter its engineering properties. Their efficiency depends upon the amount of dose, type of soil available and field conditions. The use of bioenzyme in soil stabilization is not very popular due to lack of awareness between engineers and non availability of standardized data. However, recently some bio-enzyme stabilized roads were constructed in various parts of India, which are performing very well.
\end{abstract}

Keywords: Bio Enzyme, Nontraditional Soil Stabilizer.

\section{INTRODUCTION}

The idea of using enzyme for stabilization in pavement construction was developed from the application of enzyme products used to treat soil in order to improve horticultural applications. A modification to the process produced a material, which was suitable for stabilization of poor ground for road traffic. When added to a soil, the enzymes increased the wetting and bonding capacity of the soil particles (1).

An enzyme is by definition an organic catalyst that speeds up a chemical reaction, that otherwise would happen at much slower rate, without becoming a part of the end product. Since the enzymes do not becomes the part of end product and are not consumed by the reaction, a very small amount of bio enzyme is required for soil stabilization. They are organic molecules that catalyze very specific chemical reactions if conditions are conducive to the reaction they facilitate. For an enzyme to be active in a soil, it must have mobility to reach at the reaction site. The pore fluid available in the soil mass provides means for mobility of the molecules of bioenzyme, the specific soil chemistry provides the reaction site, and time is needed for the enzyme to diffuse to the reaction site. An enzyme would stay active in a soil until there are no more reactions to catalyze. Enzymes would be expected to be very soil specific [1].

Each enzyme is specifically tailored to promote a chemical reaction within or between other molecules. The enzymes themselves are unchanged by these reactions. They serve as a host for the other molecules, greatly accelerating the rate of normal chemical and physical reactions. The enzyme allows soil materials to become more easily wet and more densely compacted. They also improve the chemical bonding between soil particles and creating a more permanent structure that is more resistant to weathering, water penetration and wear and tear. Some information about commonly available bioenzyme products and their probable stabilization mechanism are discussed in following points.

\section{RENOLITH:}

The Renolith patented product was developed in Germany. Renolith and the cement polymer-forming road stabilization chemical was further developed in Australia in 1995-96. Renolith significantly improves the strength of soil in the cement stabilization process in a variety of roads such as heavy haul roads, highways, rural roads, pathway construction, hard stands and rail earthworks capping. It also improves the flexibility of standard cement stabilized pavements [4].

Renolith's usual application is as a mixture with water in specific proportions. This mixture is then applied to a cementbased aggregates or in-situ soils from fine sands to high plasticity clays. Renolith when thoroughly mixed and stabilized with a soil or road pavement material, cement and water produces an exothermic chemical reaction and forms a polymer which when compacted provides a very dense layer.[12]

The use of Renolith, under geotechnically controlled conditions, enables the pavement designer or contractor a number of options for pavement construction using the 
material available at site. It is a cost effective method of subgrade enhancement and pavement rehabilitation. [12]

\subsection{Mechanism of Stabilization}

The renolith stabilizer coats soil particles and creates a physical bond between the soil particles when the emulsion water evaporates, leaving a soil-polymer matrix. This soil polymer matrix have high tensile strength and flexibility, These properties can also reduce the probability of any cement-stabilized pavement cracking caused by the shrinkage of the cement or road base on compaction and can provide improved permeability characteristics.[12]

The improvement in strength depends on the ability to coat the soil particles adequately and on the physical properties of the polymer. Thus, stabilization with renolith is suitable for granular soils. It can give satisfactory result in case of fine grained soil also if used in higher proportion.[13]

\subsection{Advantage of Renolith}

1. With the use of renolith, about 20 to $40 \%$ reduction in the cost of pavement construction can be achieved.

2. There is no need to import an aggregate of required specification, hence locally available material can be used.

3. Renolith provides adequate flexibility and durability to the pavement and avoids the formation of cracks.

\subsection{Experimental Study in India}

Renolith technology has been used in some projects by the Public Works Department of Arunachal Pradesh State, in India [3] and reported cost reduction of about 20 to $30 \%$. P.W.D. Rajasthan has also undertaken some works with Renolith in 2001[11]. The pavement construction projects which have been completed using this chemical with considerable success are as follows [3]:

1. Lumla township roads under CRF and Zimithang ring road under RIDF;

2. Dirangdzong-Namthung-Sangti road under CRF and Nafra-Nakhu road under NLCPR;

3. Lhou to Mukto road under NLCPR

4. Shergaon-Doimara road ;

5. Road from PWD IB to Bali at Seijosa under RIDF.

\section{PERMAZYME}

Perma-Zyme is a compaction enzyme, when it is added to a soil and aggregate mixture; it causes the compaction of clays and silts with a much faster rate than that occurs in nature. According to the manufacturer, this enzyme is a natural organic compound, similar to proteins, which acts as a catalyst [5]. Their large molecular structures contain active sites that assist molecular bonding and interaction. The organic formulation is designed to maximize compaction and increase the natural properties of soil to optimal conditions. This enzymatic stabilizer increases the wetting action of water to help achieve a higher density during compaction and the formulation accelerates cohesive bonding of soil particles, creating a tight permanent stratum [5].

\subsection{Mechanism of Stabilization}

Perma-Zyme lowers the surface tension of water, which promotes fast and thorough penetration and dispersal of moisture. This action causes hydrated clay particles to be pressed into and to fill the voids throughout the soil, thus forming a tight, dense permanent stratum. Specifically, PermaZyme combines with the large organic molecules in the soil to form a reactant intermediary, which exchanges with the clay lattice, breaking down the clay structure and causing the cover-up effect, which prevents any further absorption of water or the resultant swelling with loss of density. This is accomplished by changing the substrate molecules of the clay (polarity of electro-negativity, ion exchange of the atoms). The engineering and index properties of soil such as plasticity, liquid limit, shear strength, swelling and shrinkage are altered by releasing pore water in the clay molecule due to which it provides more dense, cohesive and stable binding properties. The increased density lowers water permeability and discourages the migration of moisture through the soil. The enzyme is regenerated by the reaction and goes on to perform again. Because the ions are very large, little osmotic migration takes place, and intimate mixing is required. This is generally aided by the destructive effect of the organic ions on the clay lattice[6].

\subsection{Advantages of Permazyme:}

Few peer-reviewed studies have been published on enzymatic stabilizers. Khan and Sarkar[6] reported increases in unconfined compressive strength with the addition of $5 \%$ enzymes and good performance in freeze-thaw testing .

1. Perma-Zyme increases the lubricity of soil particles which allows the designated soil density to be reached with less compactive effort.

2. It promotes rapid saturation and inhibits surface evaporation, thus reduces the requirement of water upto $25 \%$ of the O.M.C.

3. Perma-Zyme is environmentally friendly and biodegradable.

\section{FUJIBETON}

The Fujibeton material, developed in Japan, is climatically stable material and suitable for stabilization of all types of soils. Basically, the product is an inorganic polymer that chemically binds with all compounds, when blended with ordinary Portland cement. The blended mix is called Fujibeton Mix, which is used for soil stabilization to improve the engineering properties of soil. The design concept is based on 
the unconfined compressive strength results determined on the given soil for different proportions of soil-Fujibeton mix and calculation of the thickness of the stabilization layer based on design CBR, wheel load and volume of traffic. The top layer of the pavement should be covered with 3 to $5 \mathrm{~cm}$ asphalt concrete. [8]

\subsection{Mechanism of Stabilization}

The dispersing agent, an important constituent of Fujibeton, gives a surface activating agent to cement particles so that relative surface area increases by 1,000 times, due to the hydration reaction process. Also the time taken for initial setting to final setting is shorter although it does take a longer time for initial setting to begin This is due to the action of $\mathrm{CaCH} 3(\mathrm{CH} 2) 16 \mathrm{COOH}$ which has the characteristics of rapidly increasing viscosity and uniformly hardening after a definite time interval. As far as cement is concerned, it is necessary to prevent water evaporation by wet curing, but for Fujibeton, due to the high water contents of some of its constituents, it is desirable to expose the surface to the air. [8]

\subsection{Experimental Study in India}

To evaluate the performance of this technology, using Fujibeton as soil stabilizer, small road stretch has been constructed within the campus of NCCBM's in Ballabhgarh. With this study, it is revealed that because of faster setting and improved CBR of stabilized soil, the rural road can be opened to traffic within a day. Due to speedier construction practices, the Fujibeton stabilized rural roads will not only be economical but also prove to be effective under constraints of traffic diversion.[9]

\subsection{Advantages of Fujibeton}

The technology is advantageous not only for locations where aggregates are not available at economical rates but also for all types of soil conditions. With the use of new soil hardening agent, the material available at the construction site may be used as it is, eliminating the need for transporting of borrow soil from long distances, thus economizing and simplifying the work process. Fujibeton improves CBR of the sub-grade and does not create shrinkage cracks and is therefore highly effective for clayey/soils. With Fujibeton, a high dry density is obtained with only minor compaction. Therefore, small and simple equipments like tractor mounted equipment are sufficient. Also, this technology does not require skilled manpower for road construction. This technology is efficient and economical for construction of embankment and subgrade \& sub-base course.

\section{TERRAZYME}

TerraZyme is a natural, non-toxic liquid, formulated using vegetable extracts and accepted all over the world as a sound and resourceful road building practice, which completely replaces the conventional granular base and the granular sub base, it emphasizes on strength, performance and higher resistance towards deformation. TerraZyme is specially formulated to modify the engineering properties of soil. They require dilution in water before application. The use of TerraZyme enhances weather resistance and also increases load bearing capacity of soils. These features are particularly evident in fine-grained soils such as clay in which the formulation affects the swelling and shrinking behavior. This formulation has the ability to change the matrix of the soil so that after compaction the soil loses its ability to reabsorb water and the mechanical benefits of compaction are not lost even after water is reapplied to the compacted soil.[14] Once the enzyme reacts with the soil, the change is permanent and the product is bio-degradable.

\subsection{Mechanism of Stabilization}

TerraZyme reacts with the adsorbed water layer of clay particle and reduces the thickness around the soil particle due to which void between the soil particles reduces and the soil particle gets closer orientation with lower compactive effort. This decreases the swelling capacity of the soil particles and also reduces permeability[2].

\subsection{Advantages of Terrazyme}

1. TerraZyme increases the durability of pavement and reduces swelling properties of soil.

2. Reduces construction cost by about $20-40 \%$ due to reduction in the transportation of materials and reuse of onsite materials.

3. The use of TerraZyme enhances weather resistance and improves load bearing capacity of soils.

\subsection{Experimental Study in India}

In India TerraZyme has been used to construct a state highway on black cotton soil in Nasik, Maharashtra. Some trial roads are also constructed in states of Tamil-Nadu, Kerala and Karnataka. In Maharashtra, Public works Department has constructed two roads using TerraZyme and a cost reduction of $18-26 \%$ is reported.[8]

It is reported that Central Road Research Institute, India, conducted laboratory tests on three types of soil- Marine clay, Cuddalore soil and Pondicherry soil treated with organic bio enzyme liquid stabilizer. The soil samples were tested for CBR, Unconfined compression strength, swelling index and indirect tensile strength. It is reported that there was significant improvement in CBR value after four weeks of curing from $1.2 \%$ to $4.5 \%$. The unconfined compressive strength was also found to increase by $104 \%$ upon treatment with bio enzyme and cured for 4 weeks. (10) 


\section{CONCLUSIONS}

[8] Chandrasekhar, B.P (2006) A Critical reviews of innovative rural road construction techniques and their impact NRRDA, New Delhi.

From the above discussion following conclusions can be drawn:

1. The bio-enzymes are non toxic, organic and biodegradable in nature. These chemicals do not harm humans, animals, fish or vegetation in normal use. These are made from organic materials and are biodegradable.

2. Bio-enzyme can also be used as a dust control agent, as $75 \%$ reduction in dust on unsurfaced roads is reported in many construction work where bio-enzyme have been used[12].

3. With the use of bio-enzyme, aggregate free pavement is possible as its use promotes the use of locally available material.

4. Use of bio-enzymes results in higher compressive strength and increased hardness of stabilized soil.

5. Bio-enzymes provide flexibility and durability to the pavement and also reduce the formation of crack.

6. Bio-enzymes reduce swelling and shrinkage properties of highly expansive clays.

7. The use of bio-enzyme in pavement construction is proven to be very economical as compared to other traditional soil stabilization methods. The cost of construction project can be reduced considerably with the use of bio-enzyme.

\section{REFERENCES}

[1] Tingle J.S, et al (2007). Stabilization Mechanisms of Non-traditional Stabilizers. In Transportation Research Record: Journal of the Transportation Research Board, No. 1989, Vol.2, Transportation Research Board of the National Academies, Washington, D.C., pp. 59-67.

[2] Velasquez R., M.O. Marasteanu, R. Hozalski \& T. Clyne (2005). Preliminary Laboratory investigation of Enzyme solutions as a soil stabilizer. Research Report MN/RC-2005-25. University of Minnesota, USA.

[3] Report on Innovative Road Construction is using Renolith, by PWD Arunachal Pradesh, India, 2007.

[4] NRG Technology International Ltd (2012) "NRGRenolith-Presentation-august 2011-updated-May2012.

[5] Perma-Zyme 11X. The Charbon Group, LLC Products Division, Huntington Beach, CA, Version: No. 5450, June 1998.

[6] Khan L.I. and M. Sarker.(1993) Enzyme Enhanced Stabilization of Soil and Fly Ash. Fly Ash for Soil Improvement. ASCE GSP 36. New York. 1993. 4358.

[7] Rauch, A.F., J.S. Harmon, L.E. Katz, and H.M. Liljestrand(2002). Measured Effects of Liquid Soil Stabilizers on Engineering Properties of Clay In Transportation Research Record 1787, TRB, National Research Council. Washington, D.C. 2002, 33-41.
[9] Report on "Demonstration Project for AggregateFree Pavement Technology using Fujibeton for Rural Road Construction"(2008), NCCBM, New Delhi, India.

[10] IRC:SP:20-2002. "Rural Roads Manual", Indian Roads Congress.

[11] Report on "Demonstration Project using Soil-Cement - Renolith stabilization technique" by PWD Rajasthan, India.

[12] www.nrgrenolith.com.

[13] Rauch, A. F., Katz, L. E., and Liljestrand, H. M. (2003). An Analysis of the Mechanisms and Efficacy of Three Liquid Chemical Soil Stabilizers, Research Report 1993-1, Center for Transportation Research Bureau of Engineering Research, University of Texas at Austin, Austin, TX.

[14] Sureka Naagesh and S. Gangadhara, Swelling Properties of Bio-enzyme Treated Expansive soil, International Journal of Engineering Studies, Volume 2, Number 2 (2010), pp. 155-159. 